\title{
The Rationality of De-radicalization Efforts for the Children of Terrorists at Al-Hidayah Islamic Boarding School
}

\author{
HUSNUL ISA HARAHAP*, T. IRMAYANI \& FUAD HASAN LUBIS ${ }^{1}$
}

\begin{abstract}
Al-Hidayah Islamic Boarding School was established in 2016 in Sei Mencirim Village, Kutalimbaru Sub-District, Deli Serdang District in Sumatera. Since then it has attracted some attention from the Muslim community as it teaches the deradicalization subject and other subjects to its students who are the children of terrorists. The aim of this paper is to examine the rationality behind the deradicalization efforts taking place at the school. This study refers to some of the theories on radicalism and terrorism presented by Mark Juergensmeyer (2001), Mia Bloom (2007), Daniel Koehler (2016) and Hafal Ahmad (2017). This study uses the quantitative research methodology to gather the needed data for its findings or results. Among the findings are the de-radicalization process for the children of terrorists is a rational effort. The participation of former terrorists in the program is also a rational choice. However, there are some important aspects to be reviewed and improved by the school in order to maintain and achieve the planned goals or aims for the school. Firstly, it is necessary to strengthen the teachers' quality and quantity in the teaching the subjects offered by the school. Secondly, the design and implementation of the de-radicalization subject and other subjects need to be measured and tested regularly covering the contents of the subjects and their teaching aids. Thirdly, it is necessary to set indicators that can be used to measure the progress and success of the school from time to time.
\end{abstract}

Keywords: counter-terrorism, de-radicalization, Pesantren Al Hidayah, radicalism, terrorism

Al-Hidayah Islamic Boarding School was established in 2016 in Sei Mencirim Village, Kutalimbaru Sub-District, Deli Serdang District in Sumatera, Indonesia. There are many Islamic boarding schools found in this big area or district. However, Al-Hidayah is different from the other Islamic boarding schools since It has attracted a significant attention from the Muslim communities living in the area. There are five interesting things, separating and distinguishing Al-Hidayah from other Islamic boarding schools. Firstly, its founder is a former convicted terrorist. Secondly, it is the first Islamic boarding school in Indonesia established with the specific purpose of educating the children from the terrorist families. Thirdly, it teaches the de-radicalization subject in addition to other subjects. The de-radicalization subject is considered as unfamiliar or unusual subject for the Islamic boarding schools in Indonesia. Fourthly, some of the important dignitaries in Indonesia participated in its inauguration, such as the Head of BNPT (National Agency for Combating Terrorism) Tito Karnavian, who was appointed KAPOLRI (the National Police Chief of

\footnotetext{
${ }^{1}$ Husnul Isa Harahap* (corresponding author), lecturer at Department of Political Science, Universitas Sumatera Utara, SUMATERA UTARA PROVINCE, Indonesia, email: husnul.harahap@usu.ac.id; T. Irmayani, lecturer at Department of Political Science, Universitas Sumatera Utara, SUMATERA UTARA PROVINCE, Indonesia, email: Tengku.irmayani@gmail.com; Fuad Hasan Lubis, assist. lecturer at Department of Political Science, Universitas Sumatera Utara, SUMATERA UTARA PROVINCE, Indonesia, email: fufu.lubis@gmail.com.
} 
the Republic of Indonesia) in 2016. Fifthly, some media outlets were particularly quick to report on this school and its uniqueness. The media coverages or reports can be generally categorized into four different types depending on their focuses. The first type focuses on supporting the school on by reporting the approvals and achievements of the school has gained. The second type focuses on the school's founder, a former terrorist. The third type focuses on the students consisting of the children of terrorists. The fourth type focuses on the hopes and expectations of the positive impacts coming out from this school in eradicating and eliminating the radicals and terrorists as well as their radicalism and terrorism in Indonesia.

The Indonesian Muslim society and media have welcomed the establishment of this school with much enthusiasm and this school has gained the attention of international mass media outlets. It has been viewed positively as a positive step towards preventing the development of radicalism and terrorism in Indonesia. Thus, the school has subsequently secured a good public image in Indonesia. However, there are issues posed by some observers about this special boarding school such as the school ability to sustain its public good image and reputation, the teaching materials, the qualifications of teachers and their number and finally the financial sources to maintain the school and its subjects and program of the de-radicalization.

From an institutional perspective, the successful creation of a positive and good public image needs to be followed by in-depth studies and research to analyse the effectiveness of the school's de-radicalization courses and activities, and more importantly, to further understand about the efforts aiming at preventing and combating radicalism and terrorism in order to improve the de-radicalization courses and programs. If the school is able to maintain its positive and good public image and reputation, its courses and activities can serve as an exemplary or model school for other educationists or institutionists in other parts of Indonesia.

The concept of de-radicalization is an interesting topic to study, especially in relation to Al-Hidayah Islamic Boarding School. However so far, this topic has not attracted the attention of researchers for a number of reasons. Firstly, the study of de-radicalization is still very new. Secondly, it is still considered a taboo to talk or discuss about de-radicalization since it links with some persons known as the radicalists who are not welcomed by Indonesians at large because they oppose the radicalists and their radicalization and radicalism. Thirdly, the availability of references and resources on radicalism and de-radicalism as well as radicalization and deradicalization materials is still very limited as evident from the scanty books and journals in Indonesian language and English on radicalism and radicalization and their antonyms in the book stores in Sumatera as well as in other Indonesian provinces.

This study focuses on the de-radicalization as a new subject being taught at Al-Hidayah Islamic Boarding School that deserves to be studied in-depth. There are three expected benefits from this study. Firstly, the results of this study can be considered as an exposition and evaluation of the de-radicalization subject itself. Secondly, this study suggests ways in which the teaching contents and aids for the de-radicalization subject for its improvement. Thirdly, this study will serve as a useful foundation for further research into the teaching methods and contents of the de-radicalization subject for other educational institutions focusing on the de-radicalization of their students.

\section{Literature Review}

Since 1999, there have been many studies covering terrorism. Leonard Weinberg (2005) in his work Global Terrorism: A Beginner Guide tries to distinguish terrorism from other radical movements. He believes the acts of terror are committed to creating psychological tension, as terrorists are proud of their ability to frighten society by committing acts of terror. Meanwhile, Mia Bloom (2007) in her paper, "Female Suicide Bombers: a Global Trend", presents a theory based on despair and vengeance. According to Bloom (2007: 94): 
Women are now taking a leading role in conflicts by becoming suicide bombers using their bodies as human detonators for the explosive material strapped around their waists. The first female suicide bomber, a seventeen-year-old Lebanese girl named Sana'a Mehaydli, was sent by the Syrian Socialist National Party (SSNP/PPS), a secular, pro-Syrian Lebanese organization, to blow herself up near Israeli convoy in Lebanon in 1985, killing five Israeli soldiers. Of twelve suicide attacks conducted by SSNP, woman took part in six of them.

F. Gregory Gause III (2005: 62-76) in his work, Can Democracy Stop Terrorism? states that terrorism is related to a particular political system. Mark Juergensmeyer (2001) in his work Terror in the Mind of God: The Global Rise Religious Violence, explains the role of religion. He also mentions other contributing factors, such as ethnicity and political ideologies.

Kusrianto Ath-Thoriq (2007) in his book The Note of Political Violence: Terrorism and Power or "Catatan Kekerasan Politik: Terorisme dan Kekuasaan" assumes that terrorism is created from a belief grounded on a strongly planted ideology. He points out that this foundation does not need to be a religious one. A study by Azyumardi Azra (Effendy 1999: 145-160) provided a general review of the correlation between nationalism, ethnicity, and religion. In his research, Between Loyalty and Conflict: Nationalism, Ethnic, and Religion in Indonesia and Malaysia, Azra explains that "Islam yang dominan di kedua negara, bisa diprediksikan akan tetap menjadi salah satu isu besar dalam persoalan-persoalan politik dan ideologis... kesetiaan dan benturan nasionalisme, etnisitas dan agama" (Effendy 1999: 145-160) ["The dominant Islam in both countries is always possible to predict that it can be one of the big issues in political and ideological problems... loyalty and diverse nationalism, ethnicity and religion"]. According to Azra, Indonesia's experience of nationalism is opposed by that of religion and ethnicity.

Radical Islam which is a study by M. Zaki Mubarak (2008: 219) claims that the origins of Radical Islam in Indonesia can be found in the growth of specific political groups that adopted radical Islamist views. These groups have grown rapidly, especially after the political reformation in 1998. Their dominance has increased as a result of regional conflicts in Poso and Maluku (Mubarak 2008: 357), because the conflicts and instabilities can provide some opportunities for the radical Islamist groups to strengthen their roles in society as well as to increase their power within democratic political systems and to openly express their political views in opposing or supporting the government public policies. For example, in Indonesia, Majelis Mujahidin (Mujahidin Council) has taken the oath to uphold Islamic law in the nation (Mubarak 2008: 357). It was very different from the New Order in Indonesia when there were no radical groups dared to openly declare the radical slogans and struggles against the state policies of Indonesia.

In the study by Solahudin (2011: xi), titled NII for JI Salafi Jihadism in Indonesia or NII untuk JI Salafy Jihadism di Indonesia, Solahudin explains that the primary roots of all radical movements relate back to radical Islamism in Indonesia. He begins with the question "what kind of Islamic understanding justifies Jihad for murdering children, senior citizens, and even Moslems?" He points out that this is an important question due to the acts of terror committed on behalf of Islam. Another important question is: "where has the jihadist movement in Indonesia originated from?" "Why and how could this group adopt and implement this understanding that is frequently correlated with Al-Qaeda ideology?" (Solahudin 2011: xi). The third question is focused on explaining the context within which terrorism has developed in Indonesia.

The results of the study state that certain understandings of jihad have become the foundation for the radical Islam propagated by extremist groups: Jihad Qital Fisabililah or Jihad Fisabilillah (Holy War in the Path of Allah), Jihad Fardlu Ain (jihadas a religious obligation incumbent on all Moslems individually, even all Moslems dominated by non-Moslems), Jihad Irhabiyah (jihad allows that allows for acts of terror), and Tauhid Hakimiyah (according to which political sovereignty fully belongs to Allah) are the primary doctrines of Salafy Jihadisme (Salafy Holy War). 
According to Solahudin, radical Islamist groups are called salafy jihadists and they are determined to fight Super Power countries. These groups are concentrated in the Middle East. However, with time, these groups have spread to many parts of the world, including Southeast Asia and even Indonesia. These groups then spread their doctrine and strengthen their role by committing acts of terror. Many radical groups have been created in Indonesia that has consequently committed acts of terror.

A study in Serbia conducted in 2016 identified factors that result in radical behaviour leading to violent extremism. The study included 2,600 young respondents between the ages of 15 and 30 years old, who were considered the most vulnerable and the most likely to be directed towards violent extremism. They were citizens of the Republic of Serbia. It concluded that there were some factors that contributed to radical behaviour: firstly, the role and influence of the global and regional political system; secondly, the convergence of horizontal inequality (such as economic, civil and political exclusions, and limited opportunities for upward mobility); thirdly, injustice, corruption and persecution of certain groups; fourthly, rejection of growing social diversity; and fifthly, dissatisfaction and rejection of the economic social and political system (The Centre for Free Elections and Democracy, Belgrade, 2016). The study conducted by CESID and UNDP also discovered that these factors indirectly contributed to radical behaviour:

The findings of the research show that there is no evidence to suggest the existence of a societal process which drives young people into radical or extremist behaviour in a major way. However, the findings also identify moderate or considerable impact of several drivers in each of the surveyed regions.

Other notes from this study suggested that these factors were not necessarily similar in every region. The results demonstrated differences in the data, especially in the big cities in Southern Serbia and Southwest Serbia which served as the study areas.

The available and accessible literatures on the radicalism and terrorism reviewed here do not cover the subject of this study. Therefore, it is important to study about the efforts of deradicalization found in the Islamic boarding school in Sumatera, Indonesia named Al-Hidayah, founded and owned by the former convicted terrorist in Indonesian laws against radicalism and terrorist.

\section{Research Issues}

The terminology of "child terrorism" has been in use since 1985, with the practice gaining significant attention through Mia Bloom's study of suicide bombings in Lebanon published in 2007. Within approximately 20 years, the terminology has spread to many countries, including Indonesia. The awareness about the terrorist activities involving the children has also increased by then. Thus, the issue here is how to deal with the child terrorism. One of the popular assumptions regarding the child terrorism is that the children are easily exposed to and influenced by the radical ideologies via their parents, especially if their parents are terrorists or radicals. Al-Hidayah Islamic Boarding School was established in 2016 with the purposes of intercepting the process and overcoming the problems of the child terrorism. The issues are the roles and abilities of the school in educating, motivating, influencing as well as preventing the children of the terrorist families from becoming terrorists themselves This study looks into these issues by collecting the relevant data from the relevant respondents or informants in examining and analysing the rationality of de-radicalization efforts planned and implemented by Al-Hidayah Islamic Boarding School. The study also evaluates the rationality and reasons behind the deradicalization efforts taking place within the school campus and outside its campus involving its students and teachers. 


\section{Research Methodology and Objectives}

This study used the qualitative research method by interviewing the selected informants or respondents with the objectives of getting the relevant data for the rationality and reasons of the de-radicalization and educating efforts found at Al-Hidayah Islamic Boarding School.

The school intended to prevent the spread of radicalism and terrorism among the children. It also intended to educate and eradicate radicalism among the children registered at the school and to prevent them from being the terrorist themselves. Hopefully this study contributes to political science, particularly in the area of political ideology, and it also can contribute to the theories of radical ideology based on the events and experiences found in Indonesia. As there is an assumption that any radical ideology is spread through the learning process, the objective of this study is to assess the ability of Al-Hidayah in conducting and implementing the educational process of de-radicalization. The educational process among the children can either reduce or strengthen their ideology. The interviewers interviewed the founder of the school, the students and their parents and guardians to collect the primary data for this study. The school founder and owner are the most important informant. His name is Khairul Ghazali, the terrorist sentenced to the imprisonment for many years before he was released from the prison in 2016. After several legal charges and court proceedings, he was finally sentenced to the imprisonment for his indirect involvement of the bank robbery taken place at the CIMB Bank in Medan, North Sumatera Province on August 18th, 2010. According to the National Police Chief of the Republic of Indonesia, General Police Bambang Hendarso Danuri, "para pelaku perampokan itu mencari dana dengan tujuan untuk membantu kegiatan terorisme" (Radja 2010) ["the robbers robbed because they needed the funds to support the activities of terrorism"].

Ghazali is also known by another name, Abu Yasin. He is the founder and the owner of the school as well as the Al-Hidayah Foundation. He also teaches and plays a major role in the school de-radicalization program. As the establishment of the boarding school was originally his idea, Ghazali has provided the majority of the information on which this study is based. The interviewers interviewed him many times in order to collect the needed data from him. Some of the students and parents were also interviewed to collect the needed data from them.

\section{Study Limitations}

The researchers encountered some obstacles in collecting the needed and relevant data from the planned and selected informants namely the school founder, the students, the parents of the students or their guardians and the officers from the National Agency for Combating Terrorism in Indonesia. Firstly, the school founder and owner were busy with his jobs and responsibilities every day to complete the interview session in one time. Ghazali was needed to complete the study. The interview sessions were held many times with him in order to obtain more in-depth information. Consequently, this study may be very subjective. However, sharing its findings is, nonetheless, essential due to the rareness of studies covering the topic of de-radicalization in Islamic boarding schools.

Secondly, although the students themselves were accessible, communicating with students whose parents were known terrorists was considered as a taboo, especially when discussing terrorism or radicalism of their families. Although there were no regulations prohibiting the interviews from taking place, the researchers usually avoid the sensitive issues with the children and their parents to avoid their discomfort ability during the interview sessions. Thirdly, the head of the BNPT (National Agency for Combating Terrorism), as well as some junior members, were supposed to serve as key informants and be interviewed throughout this study. However, no interviews took place with any members of the BNPT at all. The author of this research paper sent a letter in September 2017 requesting an interview regarding Al-Hidayah Islamic Boarding School but received no response. 


\section{The Concept of De-radicalization}

There are multiple definitions of de-radicalization, such as proposed by Hafal Ahmad (2017). According to him, de-radicalization is a formal or informal approach aimed at reducing commitment to an extremist viewpoint that has led or could lead to violent action (Hafal 2017: 24). Daniel Koehler (Koehler 2016) also wrote a book, Understanding De-radicalization, Methods, Tools and Programs for Countering Violent Extremism. He described the de-radicalization program as containing particular methods, such as mentoring, vocational training or psychological counselling.

According to the BNPT, the objective of de-radicalization is "agar; kelompok inti, militan simpatisan dan pendukung meninggalkan cara-cara kekerasan dan teror dalam memperjuangkan misinya serta memoderasi paham-paham radikal mereka sejalan dengan semangat kelompok Islam moderat dan cocok dengan misi-misi kebangsaan yang memperkuat NKRI" (BNPT, n.d.) ["so that, the main team, sympathizers and supporters will leave radical ways and terror to fight for their mission and to moderate their radicalism in harmony with the spirit of moderate Islamic groups and to fit in national missions which strengthen the Unitary State of the Republic of Indonesia"].

\section{Data Analysis}

According to Neuman, to analyse data means systematically to organize, integrate, and examine, as we do this, we search for patterns and relationships among specific details. To analyse, we connect particular data to concepts, advance generalizations, and identify broad trends or themes. The analysis allows us to improve understanding, expand theory, and advance knowledge" (Neuman 2014: 477). A qualitative analysis technique was applied throughout this study. The data were obtained in the form of recordings, which were then transcribed. The interviewed data were matched with the observational and documented data. All of the relevant data were analysed by applying the theories of Mark Juergensmeyer (2001), Mia Bloom (2007), Daniel Koehler (2016) and Hafal Ahmad (2017).

\section{Educating the Children of Terrorists to Prevent Them from Becoming Terrorists Themselves}

There are two major issues of concern in the establishment of the Al-Hidayah Islamic Boarding School. The first one relates to the former terrorist who founded and owned the school. There are three main issues about him. Firstly, those who have been convicted of terrorism had been exposed to radicalism and some of them have not abandoned their radicalism after they came out from the prisons. Secondly, his school could be used to promote a kind of religiosity-based terrorism among its registered students. Thirdly, since all Islamic boarding schools are seen to be exclusive and their activities are exclusive too. He founded one of them named Al-Hidayah Islamic Boarding School.

Why did the former convicted terrorist decide to establish an Islamic boarding school? According to Khairul Ghazali, his intention was to deradicalize extreme and violent religious ideologies. This idea came to him when he was imprisoned; he was searching for answers and ways to redeem himself. After he was released from the prison, he felt he had to give a positive contribution to the State and eventually found the answer - he would devote his life to education by establishing an Islamic boarding school.

Secondly, from an economic and financing point of view, the former convicted terrorist named Ghazali was in a good position to establish his boarding school. He had made money from the books he wrote during his imprisonment. His family already ran an Islamic boarding school, Darussyifa, which was established in 2015 and later (in 2016, specifically) changed its name to Al-Hidayah. Thirdly, his idea gained the support of the BNPT (National Agency for Combating 
Terrorism) which directly participated in the opening ceremony of the school. It also helped build the school's classrooms and a mosque.

Why did Ghazali decide to welcome the children of terrorists into his school? His decision was probably motivated by three factors. Firstly, the children of terrorists in Indonesia are not in the prisons. The children of ISIS members in Iraq are put in the jails (Irak Tahan 1.300 Wanita dan Anak-Anak dari Keluarga Teroris ISIS 2017). Secondly, the children of terrorists in Indonesia are unknown. If some parents or guardians send their children to his school, they are known by the school. Thirdly, the fact is that there are no rules and regulations from the government of Indonesia on the methods of teaching and the contents of the courses for de-radicalizing the students at his school. Hence, it is open or free for the school founder and owner to teach any kind of religiosity for its students for few years.

Establishing a boarding school to educate the children of terrorists is based on the reality that not many people acknowledge their existence. The children also tend to be poorly treated. They are often insulted, isolated and ignored according to Ghazali, the school founder and owner.

Ghazali was worried about them becoming terrorists if they did not receive a proper education. He also believed they would be inclined to hate the government, as they inherit a radical ideology from their parents. Other questions are posed to Ghazali were why was the BNPT not directly involved in educating or de-radicalizing these children? And why did the BNPT support him? The answers to the two questions were Ghazali has "public ally" repented. He risked being targeted as an enemy by other terrorists when he chose to support the government's antiterrorism program. Most of the other terrorist convicts oppose his actions, and he claims they view him as a traitor. According to Ghazali, the role of the BNPT in handling terrorism is seen as irrelevant and is often considered a Taghut (worship other than Allah) among the children of terrorists. Ghazali gives a real example from his son's life. His son was bullied by his schoolmates; he was insulted as the son of a terrorist. As a result, he didn't want to go to school anymore. Ghazali was worried that his son would become resentful and seek revenge. Ghazali (2017c) said:

"Stigmatisasi anak teroris ini membuat mereka gak percaya diri, mentalnya terganggu karena sering di bully, contohnya saja anak saya di bully di sekolahnya di sekolah Muhammadiyah, satu minggu gak berani sekolah sampai kepala sekolahnya yang datang membujuk $k$ esini. Artinya dampak psikologisnya dahsya tsekali, anak-anak yang lain malah ada yang putus sekolah, berhenti dan ini kan berbahaya sekali, muncul dendam, sakit hati".

["The stigma of being the children of terrorists has made them lose their selfconfidence; their mentality is disturbed since they are always bullied. My son was bullied by his schoolmates at Muhammadiyah School. He did not dare to go to school until his teachers persuaded him. There were indications that the psychological impact was tremendous. Some other children of terrorists even dropped out from school. This is unbearable and very perilous since there will have feelings ofvengeance and resentment"].

Does it mean that there is any correlation between vengeance, radicalism, and terrorism? This study believes it is necessary to conduct a serious research into this question. Nevertheless, Ghazali points out that there is a psychological impact felt by the terrorists' children. They feel mentally shocked and insecure, experiencing social sanctions from their communities due to their parents' actions. His views support the theory of Mia Bloom (2007) on the role of vengeance in the emergence of terrorism.

Table 1. Description of the Children of Terrorists based on in-depth Interviews Ghazali

\begin{tabular}{ll}
\hline \multicolumn{1}{c}{ Identification } & \multicolumn{1}{c}{ Description } \\
\hline General behaviour & Potential to be recruited as terrorists \\
Ideological view & Tendency to carry resentment against the State \\
\hline
\end{tabular}




\begin{tabular}{ll}
\hline Psychological condition & Tendency to absorb radical ideological seeds \\
Social condition & Negative stigmatization by society \\
Economic condition & Neglected because their parents are imprisoned \\
\hline
\end{tabular}

Source: Field Research data, the Result of In-Depth Interview

Ghazali believes that the educational de-radicalization of the children of terrorists can help break the link between radicalism and terrorism in Indonesia. He said: "Jadi terorisme ini juga terjadi karena adanya dendam dan barisan sakit hat ibukan semata-mata faktor ideologis. Di dalam anak-anak ini pun sudah tertanam kebencian seperti ini. Kebencian terhadap negara, polisi, ini sudah berkembang di diri mereka dan sudah sangat familiar di kalangan mereka. Memutus mata rantai tindakan teror di Indonesia, bukan hanya Sumut ya, tapi Indonesia" (Ghazali, 2017c) ["Thus, terrorism can exist not only because of ideological factors but also because of vengeance and resentment. A feeling of resentment has been instilled in the hearts of terrorists' children, and resentment against the State and the police has developed in their minds and become very common among them. The break-off the link of terrorism is not only in North Sumatera but also in Indonesia"].

Furthermore, Ghazali explains that his specific motivation for educating the terrorists' children is to take responsibility as a repentant former terrorist. What he did in the past has contributed to the growth of radicalism, meaning that terrorism among children may implicitly be the result of his radicalism. The idea of radicalism was inherited from their radical parents. Therefore, he believes that it is the right time for him to ameliorate his past actions. He said:

\begin{abstract}
"Memperhatikan pendidikan anak-anak iniyang tidak terurus karena orang tuanya ditangkap atau mati dan negara tidak memperhatikan mereka, jadi mereka terlantar. Anak-anak ini bisa menjadi radikal dan kita akan kebanjiran teroristeroris baru dari anak-anak pelaku" (Ghazali 2017c) ["Educating these children should be prioritized since they are neglected, their parents are imprisoned or dead, and the government neglects them, so that they are really neglected. They can become radical, and we will be overwhelmed by new terrorists"].
\end{abstract}

The result of this research is different from the result of the research conducted by the Center for Free Elections and Democracy (CESID and UNDP) (The Centre for Free Elections and Democracy 2016) concerning the enabling factors which yield radical behaviour and violent extremism among children. In the case of Indonesia, the children become radical because of their parents who instil radical ideology into their children.

Ghazali is afraid that if these radical children are not taken care of, they will become a big problem for the country. If no one cares for them, they will find their own way. It is not impossible for them to be exploited and become terrorists. According to Ghazali, rehabilitation, re-education, and de-radicalization can solve this problem. What he means by rehabilitation is re-developing the souls and the mentalities of the children of terrorists, as they are isolated from their social circles and no one wants to get in touch with them; therefore, it is better to bring them to the school so that they can interact with the other students. What he means by re-education and deradicalization is that they will be taught the values of the Koran to keep them on the right path and prevent them from going astray. These children have participated in terrorist indoctrination processes alongside their parents. It means that they are the closest people to their parents. There are small cells in the terrorist networks which have been trained to committing acts of terror and promoting radicalism. They consist of the children and their parents. Once their parents are arrested, imprisoned or dead, it is possible the children will replace their parents. He said:

"Maka saya menganggap anak-anak ini memiliki 'Potensi yang tinggi' untuk melakukan tindakan teror. Ditambah lagi ketika mereka melihat langsung orang tua atau ayah mereka yang mati ditembak, dipukuli dan diinjak-injak oleh polisi 
makin memunculkan dendam di hati mereka. Jadi kita di sini berupa agar mereka semakin tidak menjadi radikal dan menanamkan pemahaman yang benar" (Ghazali 2017b) ["Therefore, I believe that these children have a "great possibility" of committing acts of terror. Besides that, when they witness their parents or their fathers being shot to death, beaten and tortured by the Police in front of them, there will be seeds of vengeance in them. Therefore, in our school, we attempt to prepare them not to be radical and lead them to the right path"].

The main good thing offered by Al-Hidayah Islamic Boarding School, according to Ghazali, is an education that prevents the children of terrorists from becoming extremists by persuading them to reject the radical ideology they have absorbed or adopted from their parents. This process is called de-radicalization for the children of terrorists, and it's designed to give them an education, attention and a new environment. This strengthens the definition of de-radicalization pointed out by Hafal Ahmad (2017). There is no difference in the definition of de-radicalization if its subjects are the children of terrorists.

\section{The De-Radicalization Method Is Still Informal}

Al-Hidayah Islamic Boarding School is a Junior High School, based on the 2013 curriculum. This curriculum is nationally applied in Indonesia. According to Ghazali, the curriculum used in this boarding school is not very different from that of Indonesian public schools. The big difference lies in the subjects of De-radicalization and Local Content.

"Kurikulum yang saat ini berlaku untuk SMP, ini SMP ya bukan tsanawiayah. Kurikulum 2013 yang dipakai . . kami tambahi mata pelajaran lokal dan deradikalisasi... kami ikuti pemerintah, tapi kalau matapelajaran tambahan kami yang susun seperti deradikalisasi dan muatan lokal" (Ghazali 2017d). ["Now the curriculum is in effect for Junior High School. Remember that this is not a Tsanawiyah (the Islamic Junior High School). We use the 2013 curriculum... we add subjects of Local Content... and de-radicalization... we follow the Government, but we organize minor subjects, such as subjects on Deradicalization and Local Content"].

The curriculum in this boarding school consists of general subjects, subjects on religious affairs and special subjects, such as Skills of Life, and De-radicalization. All these subjects contain descriptions of basic competencies and core competencies. Core competencies include attitudes toward religious affairs, attitudes toward social affairs, knowledge, and the application of knowledge. Core competencies become the reference for basic competences. The core competencies from attitudes toward religious affairs and social affairs are indirectly developed as an extension of knowledge and the application of knowledge. Basic competences are competencies that consist of attitudes, knowledge, and skills which come from core competencies.

Al-Hidayah Islamic Boarding School could potentially become the role model for educational de-radicalization programs for the children of terrorists. However, the curriculum and teaching method should be improved. In the Curriculum Department, the explanation of the subject of De-radicalization is still incomplete. In the Method Department, a written module on the de-radicalization methodology behind the de-radicalization process is not yet available. The making of modules is still in the planning stage.

"Nanti kalau kita sudah buat modul yang tertulis dan buku, diharapkan mata pelajaran ini dapat diikuti oleh seluruh sekolah di Indonesia dengan meruju kanakanak yang sudah berhasil kita rubah mindsetnya. Yaitu juga, diharapakan guruguru di sini nanti bisa juga mengajarkan deradikalisasi. Kalau perpustakaan iya tapi kita belum mampu membuat itu, diharapkan ada banyak buku tentang 
terorisme di sini nantinya, jadi pusat deradikalisasi dan kontra radikalisasi" (Ghazali 2017a) ["Later on, when we have made written modules and books, these subjects can be followed by all schools in Indonesia by referring to the students whose mindsets have been changed. It is expected that the teachers at this boarding school would teach the subjects on de-radicalization, even though we cannot afford to establish a library. We still hope that there will be a lot of books on terrorism at this boarding school which can be the centre of the deradicalization and contra-radicalization program"].

The limited teaching materials on de-radicalization mean the process of teaching relies heavily on Ghazali who points out that maximum effort is needed to strengthen the subject of Deradicalization. This has been an issue so far, with one of the problems being a lack of financing, which leads to an inability to prepare teaching materials. So far, what has been taught in Deradicalization have been stories of the Prophet Muhammad, such as those which focus on tolerance.

"Tapi kalau matapelajaran deradikalisasi dan muatan lokal belum ada, jadi di mata pelajaran itu ya saya ajarkan melalui kisah-kisah Islami saja, seperti kisah-kisah Nabi Muhammad ... rencananya saya mau mengundang para mantan teroris yang sudah sadar dan para pakar, tapi itu sulit, harus mengeluarkan dana lagi, jadi seperti FGD" (Ghazali 2017d). [However, since the subject on de-radicalization and local content has not been available, for that subject I tell my students the Islamic stories, such as the story about the Prophet Muhammad ... I plan to invite former terrorists who have repented, as well assome experts, but I realize that it is very difficult, especially regarding financial matters; it uses Focus Group Discussions (FGD)"].

According to Ghazali, particular methods are required to organize teaching materials for the De-radicalization subject, such as Focus Group Discussions (FGD). The FGD participants consist of former terrorists, experts, police officers, etc. So far, this method has not been applied, which is understandable, as it is impossible for Ghazali to organize it by himself. Supposing he could do it, it would still require support and quality control for this teaching material. Therefore, it can be said that organizing teaching materials for the subject of De-radicalization is necessary and in need of serious attention from school management, the Government or other related parties.

What has been done to support the de-radicalization of the children of terrorists in this boarding school? Al-Hidayah Islamic Boarding School uses lectures to teach de-radicalization. The material is based on Ghazali's firsthand knowledge. This method of teaching de-radicalization has been used since 2016. As of 2017, the school was still using this same method. The materials were stories of the Prophet compiled from various books. Ghazali said "Yang mata pelajaran deradikalisasi ya saya kumpulkan dari buku kisah-kisah nabi, rencananya kisah-kisah yang saya ajarkan di mata pelajaran itu nanti disatukan menjadi satu buku, itulah yang menjadi bahan ajar deradikalisasi" (Ghazali 2017d). ["I compile the materials for the subject of De-radicalization from the books about the stories of prophets. I plan to compile the stories into one book that will be used as the teaching materials for the subject of De-radicalization"]. It seems that Ghazali is greatly motivated to make teaching materials. The problem is figuring out how to create them quickly, which is, of course, not easy. If the teaching materials could be produced, the problem would then be whether and how to evaluate them. 
Tabel 2: Description of De-radicalization at Al-Hidayah Islamic Boarding School

\begin{tabular}{|c|c|c|}
\hline Identification & Description & $\begin{array}{l}\text { Additional Information } \\
\text { and Questions }\end{array}$ \\
\hline Reason for Establishment & $\begin{array}{l}\text { Terrorists' children were bullied } \\
\text { and neglected }\end{array}$ & $\begin{array}{l}\text { What do the children of } \\
\text { terrorists require? }\end{array}$ \\
\hline Objective of Establishment & $\begin{array}{l}\text { Educate the children of terrorists to } \\
\text { not be radical }\end{array}$ & What is the next step? \\
\hline $\begin{array}{l}\text { Deradicalization Teaching } \\
\text { Program }\end{array}$ & $\begin{array}{lll}\text { A Teacher } & \text { has obtained } \\
\text { deradicalization } & \text { education } & \text { from } \\
\text { BNPT } & & \end{array}$ & $\begin{array}{l}\text { Is this based on personal } \\
\text { knowledge? }\end{array}$ \\
\hline Facility and infrastructure & $\begin{array}{l}\text { Both the facilities and infrastructure } \\
\text { were available }\end{array}$ & Limited number of teachers \\
\hline Motivation to Participate & $\begin{array}{l}\text { Terrorists (parents/ former } \\
\text { terrorists) feel guilty because their } \\
\text { children are neglected }\end{array}$ & Limited number of teachers \\
\hline
\end{tabular}

Source: Field Research data, the Result of In-Depth Interview

Al-Hidayah Islamic Boarding School has other problems as well, such as a lack of teachers and budget. To date, the teachers work voluntarily; they make most of their earnings outside of the school. However, this boarding school has the potential to serve as a model for deradicalization education in Indonesia, and there are four reasons for this. Firstly, this boarding school has the initial capital required for educational activities: it has classrooms and other facilities. Secondly, it has a wide area of land that could potentially be used for economic purposes. Thirdly, it has brought good news for the local, national, and international media outlets related to the efforts of overcoming radicalism and terrorism among the children of terrorists in Indonesia. Fourthly, it gets approval from the BNPT in establishing the school even though it has noe been financially supported by the Indonesian government.

Al-Hidayah Islamic Boarding School has the potential to become a de-radicalization laboratory, creating an ideal de-radicalization model for the children of terrorists. The quality of the program should be increased by improving upon any deficiencies. Improvements will include curriculum changes, developing teaching materials, and providing other support. All of these things are needed in order for any activities within the de-radicalization program to be evaluated and measured to find out whether its goal has been achieved or not.

The de-radicalization program for the children of terrorists at Al-Hidayah Islamic Boarding School is rational when we examine the basic concept and reasons for establishing it. Conducting the de-radicalization process within the school providing an immersive and controlled environment is also a rational choice. On the other hand, this study needs to see a clear long-term plan from the school since the school cannot state clearly if its teaching contents are sufficient for a three-year program that precedes Junior High School On the expectations of its students, the school is certain that they will be familiar with one another. However, does the familiarity with each other in the school contribute positively or negatively to the deradicalization efforts? Will the children's ideology become moderate after their parents are released from their prisons? Further study is needed to answer these questions.

The existence of de-radicalization subject will strengthen the rationality of deradicalization efforts at Al-Hidayah Islamic Boarding School. Ghazali, has himself received the deradicalization education from the BNPT. He has written three books that reject terrorism and radicalism. His published books are entitled Mereka Bukan Toghut (They are not Taghut) (Ghazali 2011b), Aksi Terorisme Bukan Jihad (The Action of Terrorism is Not Jihad) (Ghazali 2015), and Aksi Perampokan Bukan Fa'i (The Action of Robbery is Not Fa'i) (Ghazali 2011a). However, these books are not used as teaching materials at his school and it is unclear how they would affect the students' performance in the context of de-radicalization. The other problems are on the teaching materials to support the de-radicalization program is the fact that the process of de-radicalization 
seems to run smoothly, even without adequate planning and teaching materials. However, it is clear the school requires more attention. Referring to Daniel Koehler's study (2016), a method is very important in the process of de-radicalization since it explains how to achieve a certain goal.

Al-Hidayah Islamic Boarding School also has general subjects, subjects on religious affairs, and school of nature. However, it still needs a teacher for each subject, and this is the main problem of this boarding school. According to Ghazali, recruiting more teachers to lessen the burden will bring out their care for the students.

Finally, conducting the de-radicalization programs in boarding schools will carry certain implications from a political and ideological standpoint. One of the possible implications is reversing the association between radicalism and boarding schools. Nowadays, Islamic boarding schools are considered places in which radicalism is promoted and developed, especially when consulting the news in various mass media outlets - the relationship between radicalism and boarding schools is usually not considered to be a positive one. This time, the conditions are reversed: Al-Hidayah Islamic Boarding School proves that boarding schools can also become places which fight radicalism through de-radicalization programs; since its establishment, there have been talks of establishing another boarding school or a school with a de-radicalization program in places such as Java. Therefore, this case should be monitored. The boarding school should be equipped with a complete and tested teaching system in order to facilitate radicalization.

To conclude, Al-Hidayah Islamic Boarding School, established in 2016, is an interesting phenomenon to be studied. This boarding school was established by a former terrorist who wanted to educate the children of terrorists. It has a unique subject, De-radicalization, which is very rare for a boarding school. This paper investigated the reasons for creating the deradicalization program for the children of terrorists at Al-Hidayah Islamic Boarding School.

The conclusion is that de-radicalization program at Al-Hidayah Islamic Boarding School is a rational effort which requires more support and better conditions in order to be fully successful in attain its stated goals or objectives. Improving the quality of the program is not as easy as increasing its popularity. The interesting and unique thing about this boarding school is that its de-radicalization program is running smoothly, despite its teaching program and materials being far from adequate. Improving upon these deficiencies is expected to create an ideal de-radicalization program model for Islamic boarding schools. The most important and serious things that need to be done are increasing the quality and capacity of its teachers and further developing the teaching contents and aids for the de-radicalization program as well as the necessary evaluation devices to measure the progress and achievements of the de-radicalization program.

This research carries some theoretical implications. Firstly, the results of this study tend to strengthen the theory on the influence of vengeance on the emergence of terrorism as proposed by Mia Bloom (2007). Furthermore, it strengthens the theory on the role of religion and other factors in the emergence and spreading of terrorism as proposed of Mark Juergensmeyer (2001).

Secondly, the conclusions of this study confirm the definition of de-radicalization as proposed by Hafal Ahmad (2017) and the theory about the need for a certain method to be applied in the de-radicalization process as proposed by Daniel Koehler (2016). The definition of deradicalization does not change when its subjects are the children of terrorists. Establishing a proper or suitable method for the de-radicalization process of the children of terrorists is indeed very important.

Thirdly, this research brings into question the results of The Centre for Free Elections and Democracy (CESID and UNDP) (2016) on the factors yielding radical behaviours and contributing to extreme violence among children. In the Indonesian case, the children who become radical because their parents have instilled the radical ideology to them, especially in the case of the children of terrorists. 


\section{Acknowledgments}

This research was financed by the University of Sumatera Utara, based on the Kontrak Penelitian Talenta (Talent Research Contract) USU Number: 5338/UN5.1.R./PPM/2017.

\section{References}

Ath-Thoriq, A. K. 2007. Catatan Kekerasan Politik: Terorisme dan Kekuasaan. Jakarta: Wacana Edukasi Madani.

Bloom, M. 2007. Female suicide bombers: s global trend. Daedalus 136(1): 94-102.

BNPT. n.d. Strategi Menghadapi Paham Radikalisme Terorisme-ISIS. Badan Nasional Penanggulangan Terorisme.

Effendy, E. A. (ed.). 1999. Dekonstruksi Islam Mazhab Ciputat. Bandung: Zaman.

Gause III, F. G. 2005, October. Can Democracy Stop Terrorism? Foreign Affairs, 84 No. 5. Retrieved from https://www.foreignaffairs.com/articles/middle-east/2005-09-01/can-democracy-stopterrorism.

Ghazali, K. 2011a. Aksi Perampokan Bukan Fa'i. Jakarta: Penerbit Grafindo Khazanah Ilmu.

Ghazali, K. 2011b. Mereka Bukan Thagut: Meluruskan Salah Paham tentang Thagut. Jakarta: Penerbit Grafindo Khazanah Ilmu.

Ghazali, K. 2015. Aksi Teror Bukan Jihad. Jakarta: Daulat Press.

Ghazali, K. 2017a, Augus. Mata Pelajaran Agama dan Deradikalisasi di Pondok Pesantren Al Hidayah Kabupaten Deli Serdang, Sumatera Utara [audio recording]. (Pondok Pesantren Al Hidayah Kabupaten Deli Serdang).

Ghazali, K. 2017b, July 10. Latar Belakang Berdirinya Pondok Pesantren Al Hidayah Kabupaten Deli Serdang, Sumatera Utara [audio recording]. (Pondok Pesantren Al Hidayah Kabupaten Deli Serdang).

Ghazali, K. 2017c July 22. Profil Lembaga Pondok Pesantren Al Hidayah Kabupaten Deli Serdang, Sumatera Utara [audio recording]. (Pondok Pesantren Al Hidayah Kabupaten Deli Serdang).

Ghazali, K. 2017d July 26. Profil Guru di Pondok Pesantren Al Hidayah Kabupaten Deli Serdang, Sumatera Utara [audio recording]. (Pondok Pesantren Al Hidayah Kabupaten Deli Serdang).

Hafal Ahmad. 2017. Youth de-radicalization: A Canadian framework. Journal for Deradicalization. 12(Fall): 119-168.

Irak Tahan 1.300 Wanita dan Anak-Anak dari Keluarga Teroris ISIS. (2017, November 9). Kompas.Com. Retrieved from http://internasional.kompas.com/read/2017/09/11/22002461/irak-tahan1300-wanita-dan-anak-anak-dari-keluarga-teroris-isis.

Juergensmeyer, M. 2001. Terror in The Mind of God: The Global Rise Religious Violence. Barkeley and London: University of California.

Koehler, D. 2016. Understanding Deradicalization: Methods, Tools and Programs for Countering Violent Extremism, 1st Edition. Retrieved from https://doi.org/10.4324/9781315649566.

Mubarak, M. Z. 2008. Genealogi Islam Radikal di Indonesia: Gerakan, Pemikiran dan Prospek Demokrasi. Jakarta: LP3ES.

Neuman, W. L. 2014. Social Research Methods: Qualitative and Quantitative Approaches (Seventh edition). United States of America: Pearson.

Radja, A. M. 2010, September 20. Kapolri: Perampokan Bank CIMB Niaga Terkait Terorisme. Antaranews.com. Retrieved from https://www.antaranews.com/berita/221381/kapolriperampokan-bank-cimb-niaga-terkait-terorisme.

Solahudin. 2011. NII Sampai JI: Salafy Jihadisme di Indonesia. Jakarta: Komunitas Bambu.

The Centre for Free Elections and Democracy, Belgrade. 2016. Survey of the Drivers of Youth Radicalism and Violent Extremism in Serbia (pp. 1-27) [SURVEY REPORT]. Retrieved from CeSID and UNDP website: http://www.rs.undp.org/content/dam/serbia/Publications\%20and\%20 reports/English/Resilience/UNDP_SRB_drivers\%20of\%20youth\%20radicalism $\% 20$ and $\% 2$ 0violent\%20extremism.pdf?download.

Weinberg, L. 2005. Global Terrorism: A Beginner Guide. England: One World Oxford. 